Accepted for publication in Angewandte Chemie

\title{
Formic Acid Dehydrogenation on Au-Based Catalysts at Near-Ambient Temperatures
}

\author{
Manuel Ojeda and Enrique Iglesia* \\ Department of Chemical Engineering, University of California \\ and \\ Chemical Sciences Division, E.O. Lawrence Berkeley National Laboratory, \\ Berkeley, CA, USA \\ *corresponding author (iglesia@berkeley.edu)
}


Formic acid $(\mathrm{HCOOH})$ is a convenient hydrogen carrier in fuel cells designed for portable use. ${ }^{[1-}$ 4] Recent studies have shown that $\mathrm{HCOOH}$ decomposition is catalyzed with Ru-based complexes in the aqueous phase at near-ambient temperatures. ${ }^{[5,6]} \mathrm{HCOOH}$ decomposition reactions are used frequently to probe the effects of alloying and cluster size and of geometric and electronic factors in catalysis ${ }^{[7-10]}$. These studies have concluded that $\mathrm{Pt}$ is the most active metal for $\mathrm{HCOOH}$ decomposition, at least as large crystallites and extended surfaces ${ }^{[9]}$. The identity and oxidation state of surface metal atoms influence the relative rates of dehydrogenation $\left(\mathrm{HCOOH} \rightarrow \mathrm{H}_{2}+\mathrm{CO}_{2}\right)$ and dehydration $\left(\mathrm{HCOOH} \rightarrow \mathrm{H}_{2} \mathrm{O}+\mathrm{CO}\right)$ routes, a selectivity requirement for the synthesis of $\mathrm{CO}$-free $\mathrm{H}_{2}$ streams for low-temperature fuel cells. Group Ib and Group VIII noble metals catalyze dehydrogenation selectively, while base metals and metal oxides catalyze both routes, either directly or indirectly via subsequent water-gas shift (WGS) reactions ${ }^{[8,11-13]}$.

Mars et al. ${ }^{[8]}$ concluded that formates act as intermediates in $\mathrm{HCOOH}$ decomposition; their formation limits rates on nobler metals $(\mathrm{Au}, \mathrm{Ag})$ and its decomposition on the others. $\mathrm{Au}$ catalysts previously gave lower areal rates than other metals, as expected from its inertness for $\mathrm{HCOOH}$ dissociation, evident in its first-order $\mathrm{HCOOH}$ decomposition kinetics ${ }^{[14]}$. Small $\mathrm{Au}$ clusters $(<5 \mathrm{~nm})$ deposited on oxide supports catalyze many reactions at turnover rates higher than larger clusters, apparently because coordinatively unsaturated or non-zero valent species bind molecules more strongly than low-index surfaces on larger crystallites ${ }^{[15-18]}$.

This study shows that well-dispersed $\mathrm{Au}$ species grafted onto $\gamma-\mathrm{Al}_{2} \mathrm{O}_{3}$ give significantly higher $\mathrm{HCOOH}$ metal-time yields (on the basis of the total number of metal atoms) ${ }^{[19]}$ than even $\mathrm{Pt}$ clusters. Decomposition occurs at near ambient temperatures $(\sim 350 \mathrm{~K})$ and forms only $\mathrm{H}_{2}$ and $\mathrm{CO}_{2}$, suitable for direct use in fuel cells. In contrast with pathways on $\mathrm{Pt}, \mathrm{HCOOH}$ decomposes on dispersed $\mathrm{Au}$ species via $\mathrm{H}$-assisted bimolecular formate decomposition instead of via well- 
established unimolecular analogs. This remarkable reactivity arises from dispersed Au species, undetectable by electron microscopy, which grew during thermal treatments, instead of from the predominant Au metal clusters (3-4 nm) evident in micrographs, which are unaffected by thermal treatments and catalyze $\mathrm{CO}$ oxidation.

$\mathrm{HCOOH}$ decomposition metal-time yields on well-dispersed Au species (Figure 1) are much higher than on Pt clusters at all temperatures (343-383 K). These higher metal-time yields do not reflect metal dispersion differences $(0.28$ for $\mathrm{Au}$ and 0.21 for $\mathrm{Pt}$, based on size of clusters visible in transmission electron micrographs (TEM)). Activation energies in the zero-order $\mathrm{HCOOH}$ kinetic regime were $53 \pm 2$ and $72 \pm 4 \mathrm{~kJ} \mathrm{~mol}^{-1}$ for $\mathrm{Au}$ and $\mathrm{Pt}$, respectively, in reasonable agreement with previous reports (40-60 and 58-73 $\mathrm{kJ} \mathrm{mol}^{-1}$ for $\mathrm{Au}$ and $\mathrm{Pt}$, respectively ${ }^{[14,20-22]}$ ).

$\mathrm{HCOOH}$ dehydrogenation turnover rates increased with decreasing Pt cluster size (Figure 2). Thermal treatment of $\mathrm{Au} / \mathrm{Al}_{2} \mathrm{O}_{3}$ in flowing $\mathrm{O}_{2} / \mathrm{He}$ flow at temperatures up to $1073 \mathrm{~K}$ led to a marked decrease in turnover rates without a concurrent increase in the size of Au clusters detectable by TEM (Supporting Information). This indicates that $\mathrm{Au}$ species active in $\mathrm{HCOOH}$ decomposition do not reside on surfaces of the TEM-visible clusters. $\mathrm{HCOOH}$ dehydrogenation and water-gas shift (WGS) reactions have been proposed to involve formate-type species. Indeed, we find that WGS rates also decreased markedly upon thermal treatment, while CO oxidation rates remain essentially unchanged (Figure 3). Thus, we conclude that CO oxidation, but not WGS or $\mathrm{HCOOH}$ dehydrogenation, occurs on active sites provided by the Au metal clusters detected in the micrographs. Our data indicate that $\mathrm{HCOOH}$ dehydrogenation and WGS reactions occur on similar Au species, undetectable by TEM and present as much smaller clusters or even atomically-dispersed structures, as proposed recently for WGS reactions on $\mathrm{Au} / \mathrm{CeO}_{2}$ catalysts ${ }^{[23]}$. These species account for the remarkable reactivity of Au-based catalysts 
in $\mathrm{HCOOH}$ dehydrogenation. Such isolated Au species coalesce at higher temperatures to form Au metal clusters with much lower $\mathrm{HCOOH}$ dehydrogenation reactivity.

$\mathrm{Au} / \mathrm{TiO}_{2}$ catalysts (World Gold Council, treated in $\mathrm{O}_{2} / \mathrm{He}$ at $523 \mathrm{~K}$ ) with a cluster size distribution similar to that in $\mathrm{Au} / \mathrm{Al}_{2} \mathrm{O}_{3}$ (treated in $\mathrm{O}_{2} / \mathrm{He}$ at $873 \mathrm{~K}$ ) gave lower metal-time yields for $\mathrm{HCOOH}$ dehydrogenation (7vs. $\left.201 \mathrm{~mol} \mathrm{g-at} \mathrm{Au}^{-1} \mathrm{~h}^{-1}\right)$, apparently because of smaller concentrations of isolated $\mathrm{Au}$ species than even on $\mathrm{Au} / \mathrm{Al}_{2} \mathrm{O}_{3}$ samples treated at $873 \mathrm{~K}$. In contrast, $\mathrm{CO}$ oxidation rates were similar on these two samples $\left(\sim 2.6 \mathrm{~mol} \mathrm{~g}\right.$-at $\mathrm{Au}_{\mathrm{s}}^{-1} \mathrm{~s}^{-1}$ at $288 \mathrm{~K}, \mathrm{CO}(5 \mathrm{kPa}), \mathrm{O}_{2}(2$ $\mathrm{kPa})$ and $\left.\mathrm{H}_{2} \mathrm{O}(0.5 \mathrm{kPa})\right)$, consistent with active sites located in the Au clusters detected by TEM, which were of similar size in $\mathrm{Au} / \mathrm{TiO}{ }_{2}$ and $\mathrm{Au} / \mathrm{Al}_{2} \mathrm{O}_{3}$ samples $(3-4 \mathrm{~nm})$.

$\mathrm{Au} / \mathrm{Al}_{2} \mathrm{O}_{3}$ and $\mathrm{Pt} / \mathrm{Al}_{2} \mathrm{O}_{3}$ formed only $\mathrm{H}_{2}$ and $\mathrm{CO}_{2}$ from $\mathrm{HCOOH}$ and neither dehydration nor reverse WGS products were detected. Dehydrogenation rates were independent of $\mathrm{HCOOH}$ pressure $\left(0.25-8 \mathrm{kPa}\right.$ ) on $\mathrm{Au} / \mathrm{Al}_{2} \mathrm{O}_{3}$ (Figure 4). In contrast, rates first increased with $\mathrm{HCOOH}$ pressure and then reached constant values at $>2 \mathrm{kPa} \mathrm{HCOOH}$ on $\mathrm{Pt} / \mathrm{Al}_{2} \mathrm{O}_{3}$. Zero-order $\mathrm{HCOOH}$ kinetics indicate that surfaces are saturated with reactive intermediates with rates determined by their decomposition, as in the case of (a) dissociative adsorption of $\mathrm{HCOOH}$ and decomposition of the resulting formates unimolecularly or bimolecularly on saturated surfaces, or $(b)$ bimolecular reactions of saturated formates with $\mathrm{HCOOH}$ molecules adsorbed on a separate site also at saturated coverages.

$\mathrm{H} / \mathrm{D}$ kinetic isotope effects (KIE) were used to discriminate among these mechanistic possibilities. Kinetically-relevant dissociation would give normal KIE values $\left(r_{H} / r_{D}>1\right)$ for HCOOD, but not for $\mathrm{DCOOH}$. Rate-limiting formate decomposition would lead to normal KIE values for $\mathrm{DCOOH}$, but not for HCOOD. On $\mathrm{Pt} / \mathrm{Al}_{2} \mathrm{O}_{3}$, small normal KIE values (Table 1), typical of thermodynamic isotope effects, were observed for HCOOD, and much larger values for both $\mathrm{DCOOH}$ and DCOOD, consistent with kinetically-relevant formate dehydrogenation via unimolecular $\mathrm{C}-\mathrm{H}(\mathrm{D})$ 
bond cleavage (mechanism a). On $\mathrm{Au} / \mathrm{Al}_{2} \mathrm{O}_{3}$, all isotopomers gave $\mathrm{KIE}$ values of apparent kinetic origin. These $\mathrm{KIE}$ values on $\mathrm{Au} / \mathrm{Al}_{2} \mathrm{O}_{3}$ do not reflect $\mathrm{DCOOH} \leftrightarrows \mathrm{HCOOD}$ scrambling during dehydrogenation, because isotopic mixing was not detected on either Au or Pt catalysts. Binomial dihydrogen isotopomers formed on $\mathrm{Pt} / \mathrm{Al}_{2} \mathrm{O}_{3}$, while $\mathrm{HD}$ was the only dihydrogen isotopomer formed during $\mathrm{HCOOD}$ and $\mathrm{DCOOH}$ dehydrogenation on $\mathrm{Au} / \mathrm{Al}_{2} \mathrm{O}_{3}$, indicating that surface $\mathrm{H}$-atoms are unable to recombine on $\mathrm{Au}$ active sites. Dihydrogen must therefore form via reactions of methyl hydrogen atoms in formate groups with hydroxyl-derived $\mathrm{H}$ atoms, without isotopic mixing or recombinative desorption of $\mathrm{H}$-atoms on Au active sites.

KIE values and dihydrogen isotopomers on $\mathrm{Au} / \mathrm{Al}_{2} \mathrm{O}_{3}$ are inconsistent with sequential $\mathrm{HCOOH}$ dissociation and unimolecular formate decomposition. A sequence of elementary steps consistent with these kinetic and isotopic data on Au catalysts is shown in Scheme $1 . \mathrm{HCOOH}$ adsorbs dissociatively to give formates in quasi-equilibrated steps, which then decompose to give $\mathrm{CO}_{2}$ and $\mathrm{H}_{2}$ in a step assisted by $\mathrm{H}$-atoms previously formed via $\mathrm{HCOOH}$ dissociation, and which do not recombine on Au to form dihydrogen. This kinetically-relevant step accounts for the normal KIE values measured for all formic acid isotopomers on Au catalysts and for the exclusive formation of $\mathrm{HD}$ from $\mathrm{DCOOH}$ and HCOOD. On Pt catalysts, quasi-equilibrated recombinative hydrogen desorption scrambles hydrogen isotopes and formate species are decomposed via unassisted pathways, because hydrogen recombination can complete catalytic cycles.

On Au catalysts, the assumption of pseudo-steady-state for all adsorbed species in Scheme 1 gives the following rate equation assuming $\mathrm{HCOO}^{*}$ and $\mathrm{H}^{*}$ as the most abundant surface intermediates:

$$
r_{\mathrm{HCOOH}}=\frac{\mathrm{K}_{1} \mathrm{k}_{2} \mathrm{P}_{\mathrm{HCOOH}}}{\left(1+2 \mathrm{~K}_{1}^{1 / 2} \mathrm{P}_{\mathrm{HCOOH}}^{1 / 2}\right)^{2}}
$$


which simplifies to $\mathrm{r}_{\mathrm{HCOOH}}=\mathrm{k}_{2} / 4$ when rates become independent of $\mathrm{HCOOH}$ pressures, as suggested by the data in Figure 4. Thus, dehydrogenation rates depend on the rate constant for step 2 and on the isotopic identity of both hydroxyl and carbonyl hydrogens in formic acid.

The exclusive formation of $\mathrm{HD}$ from $\mathrm{HCOOD}$ and $\mathrm{DCOOH}$ indicates that dihydrogen forms in irreversible steps, a situation that gives rise to a chemical potential of hydrogen much higher at active sites (within the $\mathrm{H}$-containing intermediates that form $\mathrm{H}_{2}$ ) than in the $\mathrm{H}_{2}$ present in the contacting gas phase, as shown by the non-equilibrium thermodynamic treatments of chemical kinetics of DeDonder and Boudart ${ }^{[24,25]}$. Thus, the driving force for any reaction using hydrogen as a reactant, whether at electrodes or in cross-hydrogenation reactions, would be much higher during $\mathrm{HCOOH}$ dehydrogenation than at the $\mathrm{H}_{2}$ pressure prevalent during catalysis. We conclude that $\mathrm{HCOOH}$ can be used as an in situ source of hydrogen at high chemical potentials on isolated Au species, because these species do not equilibrate surface and gas phase hydrogen pools during $\mathrm{HCOOH}$ dehydrogenation.

In summary, well-dispersed $\mathrm{Au}$ species grafted onto $\gamma-\mathrm{Al}_{2} \mathrm{O}_{3}$, undetectable by electron microscopy, dehydrogenate $\mathrm{HCOOH}$ with much higher metal-time yields than $\mathrm{Pt}$ clusters, previously considered to be the most active catalyst for this reaction. $\mathrm{HCOOH}$ dehydrogenation proceeds via a $\mathrm{H}$-assisted formate decomposition mechanism, leading to $\mathrm{H}_{2} / \mathrm{CO}_{2}$ streams wellsuited for direct use in low-temperature fuel cells and to surface hydrogen chemical potentials of potential use in the upgrading of unsaturated or oxygenated molecules via cross-hydrogenation catalysis. These Au species also catalyze water-gas shift, but $\mathrm{CO}$ oxidation occurs instead on Au metal clusters detectable by transmission electron microscopy. 


\section{Experimental Section}

The $\mathrm{Au} / \mathrm{Al}_{2} \mathrm{O}_{3}$ catalyst $\left(0.61\right.$ wt.\%) was prepared by the deposition-precipitation (DP) ${ }^{[26]}$. $\mathrm{HAuCl}_{4} \cdot \mathrm{xH}_{2} \mathrm{O}(0.24 \mathrm{~g}$, Aldrich, $99.999 \%)$ was dissolved in deionized $\mathrm{H}_{2} \mathrm{O}\left(80 \mathrm{~cm}^{3}\right)$ at $353 \mathrm{~K}$. The support ( $5 \mathrm{~g}, \gamma-\mathrm{Al}_{2} \mathrm{O}_{3}$, Alcoa) was treated in air at $923 \mathrm{~K}$ for $5 \mathrm{~h}$, and suspended in $\mathrm{H}_{2} \mathrm{O}\left(120 \mathrm{~cm}^{3}\right)$ at $353 \mathrm{~K}$. Au deposition onto $\mathrm{Al}_{2} \mathrm{O}_{3}$ was performed at $353 \mathrm{~K}$ and $\mathrm{pH}=7$ (adjusted with $\mathrm{NaOH} 0.5$ M) by stirring both solutions together for $1 \mathrm{~h}$. The solid was filtered and washed twice with water at room temperature and then once with warm water (323 K), followed by drying at room temperature for $24 \mathrm{~h}$. The Au content is $0.61 \mathrm{wt} . \%$ (Galbraith Laboratories, Inc.). Three different portions were treated in $\mathrm{O}_{2} / \mathrm{He}\left(25 \mathrm{vol} . \%, 25 \mathrm{~cm}^{3} \mathrm{~g}^{-1} \mathrm{~s}^{-1}\right)$ by increasing the temperature from ambient to 873,950 and $1023 \mathrm{~K}$ at $0.17 \mathrm{~K} \mathrm{~s}^{-1}$ and holding at each temperature for $2 \mathrm{~h}$. The $\mathrm{Au} / \mathrm{TiO}_{2}$ material (1.56 wt.\%, 3.3 $\pm 0.7 \mathrm{~nm}$ ) was prepared by DP and supplied by the World Gold Council. Pt catalysts (2 wt.\%) with different metal cluster size were prepared by Nanostellar using colloidal methods ${ }^{[27]}$.

$\mathrm{HCOOH}$ decomposition, WGS and $\mathrm{CO}$ oxidation rates were measured in a packed-bed reactor. The catalyst (30-100 mg) was diluted with quartz particles (washed with $\mathrm{HNO}_{3}$ and treated in air at $1023 \mathrm{~K}$ for $5 \mathrm{~h}$ ) and pretreated in situ in flowing pure $\mathrm{H}_{2}$ at $373 \mathrm{~K}$ (heating rate of $0.17 \mathrm{~K} \mathrm{~s}^{-1}$ ) for $0.5 \mathrm{~h}$ and then in a mixture $\mathrm{H}_{2} \mathrm{O} / \mathrm{H}_{2}\left(1\right.$ vol.\% $\left.\mathrm{H}_{2} \mathrm{O}\right)$ at $373 \mathrm{~K}$ for $0.5 \mathrm{~h}{ }^{[28]}$. Gas reactants $(\mathrm{He}$, 10 vol. $\% \mathrm{CO} / \mathrm{He}, 25$ vol\% $\mathrm{O}_{2} / \mathrm{He}$, Praxair, UHP) were introduced with mass-flow controllers, while liquid $\mathrm{HCOOH}$ (Acros, 99\% pure) and $\mathrm{H}_{2} \mathrm{O}$ were fed with a syringe pump (Cole Parmer 74900 Series). KIE were measured by using deuterated formic acid (Cambridge Isotope Laboratories, 98\%). Reactants and products concentrations were determined on line with a mass spectrometer (Inficon Transpector) and a gas chromatograph (Hewlett-Packard 6890GC) equipped with a Porapak Q packed column (80-100 mesh, $1.82 \mathrm{~m} \times 3.18 \mathrm{~mm}$ ) connected to a thermal conductivity detector. 


\section{Acknowledgements}

M. Ojeda acknowledges financial support from the European Union (Marie Curie Actions). This work was supported by the Director, Office of Basic Energy Sciences, Chemical Sciences Division of the U.S. Department of Energy under Contract DE-AC02-05CH11231. We acknowledge $\mathrm{H}$. Kung and M. Kung (Northwestern University) for an initial catalyst sample and for detailed procedures that allowed us to reproduce their synthesis protocols. The expert assistance of M. Avalos, L. Rendon and F. Ruiz from the Centro de Ciencias de la Materia Condensada, UNAM, Mexico in transmission electron microscopy is also acknowledged with thanks.

\section{References}

[1] C. Rice, R.I. Ha, R.I. Masel, P. Waszczuk, A. Wieckowski, T. Barnard, J. Power Sources 2002, 111, 83.

[2] X. Yu, P.G. Pickup, J. Power Sources 2008, 182, 124.

[3] S. Enthaler, ChemSusChem 2008, 1, 801.

[4] F. Joó, ChemSusChem 2008, 1, 805.

[5] B. Loges, A. Boddien, H. Junge, M. Beller, Angew. Chem. Int. Ed. 2008, 47, 3962.

[6] C. Fellay, P.J. Dyson, G. Laurenczy, Angew. Chem. Int. Ed. 2008, 47, 3966.

[7] R.J. Madix, Catal. Rev. Sci. Eng. 1984, 26, 281.

[8] P. Mars, J.J.F. Scholten, P. Zwietering, Adv. Catal. 1963, 14, 35.

[9] M.A. Barteau, Catal. Letters 1991, 8, 175.

[10] E. Iglesia, M. Boudart, J. Phys. Chem. 1991, 95, 7011.

[11] J.M. Trillo, G. Munuera, J.M. Criado, Catal. Rev. 1972, 7, 51.

[12] R. Larsson, M.H. Jamroz, M.A. Borowiak, J. Molec. Catal. A: Chem. 1998, 129, 141.

[13] K.S. Kim, M.A. Barteau, Langmuir 1988, 4, 945.

[14] W.M.H. Sachtler, J. Fahrenfort, Actes du Deuxieme Congres Internationale de Catalyse $1961,831$.

[15] H.H. Kung, M.C. Kung, C.K. Costello, J. Catal. 2003, 216, 425.

[16] G.C. Bond, D.T. Thompson, Gold Bull. 2000, 33, 41.

[17] D. Andreeva, Gold Bull. 2002, 35, 82. 
[18] A.S.K. Hashmi, G.J. Hutchings, Angew. Chem. Int. Ed. 2006, 45, 7896.

[19] M. Boudart, G. Djéga-Mariadassou, Kinetics of heterogeneous catalytic reactions; Princeton University Press: Princeton, N.J., 1984.

[20] W.J. Chun, K. Tomishige, M. Hamakado, Y. Iwasawa, K. Asakura, J. Chem. Soc., Faraday Trans. 1995, 91, 4161.

[21] M.M. Mohamed, M. Ichikawa, J. Colloid Interf. Sci. 2000, 232, 381.

[22] J. Block, J. Vogl, Z. Elektrochem. 1959, 63, 3.

[23] Q. Fu, H. Saltsburg, M. Flytzani-Stephanopoulos, Science 2003, 301, 935.

[24] M. Boudart, Catal. Letters 1989, 3, 111.

[25] S.Y. Yu, J.A. Biscardi, E. Iglesia, J. Phys. Chem. B 2002, 106, 9642.

[26] M. Haruta, Catal. Today 1997, 36, 153.

[27] A.D. Allian, K. Takanabe, K.L. Fujdala, X. Hao, T.J. Truex, E. Iglesia, in preparation 2008.

[28] C.K. Costello, J. Guzman, J.H. Yang, Y.M. Wang, M.C. Kung, B.C. Gates, H.H. Kung, J. Phys. Chem. B 2004, 108, 12529. 
Table 1. Kinetic isotope effects for formic acid decomposition at $353 \mathrm{~K}$ with $\mathrm{Pt} / \mathrm{Al}_{2} \mathrm{O}_{3}(\mathrm{~d}=0.21,4$ $\mathrm{kPa})$ and $\mathrm{Au} / \mathrm{Al}_{2} \mathrm{O}_{3}(\mathrm{~d}=0.28,2 \mathrm{kPa})$.

\begin{tabular}{ccc}
\hline & \multicolumn{2}{c}{ Kinetic Isotope Effect } \\
\cline { 2 - 3 } & $\mathrm{Pt} \mathrm{Al}_{2} \mathrm{O}_{3}$ & $\mathrm{Au} / \mathrm{Al}_{2} \mathrm{O}_{3}$ \\
\hline $\mathrm{HCOOD}$ & 1.1 & 1.6 \\
$\mathrm{DCOOH}$ & 1.7 & 2.5 \\
$\mathrm{DCOOD}$ & 2.1 & 4.7 \\
\hline
\end{tabular}

Scheme 1. Proposed elementary steps for $\mathrm{HCOOH}$ dehydrogenation on well-dispersed $\mathrm{Au}$ species.

1. $\mathrm{HCOOH}+2^{*} \nrightarrow \mathrm{HCOO}^{*}+\mathrm{H}^{*}$

2. $\mathrm{HCOO}^{*}+\mathrm{H}^{*} \longrightarrow \mathrm{CO}_{2}+\mathrm{H}_{2}+2^{*}$ 
Figure 1. Arrhenius plot for $\mathrm{HCOOH}$ decomposition (mol h $\mathrm{h}^{-1}$ g-at metal $\left.{ }^{-1}\right)$ on $\mathrm{Au}^{-} / \mathrm{Al}_{2} \mathrm{O}_{3}(2 \mathrm{kPa}$ $\mathrm{HCOOH})$ and $\mathrm{Pt} / \mathrm{Al}_{2} \mathrm{O}_{3}(4 \mathrm{kPa} \mathrm{HCOOH})$.

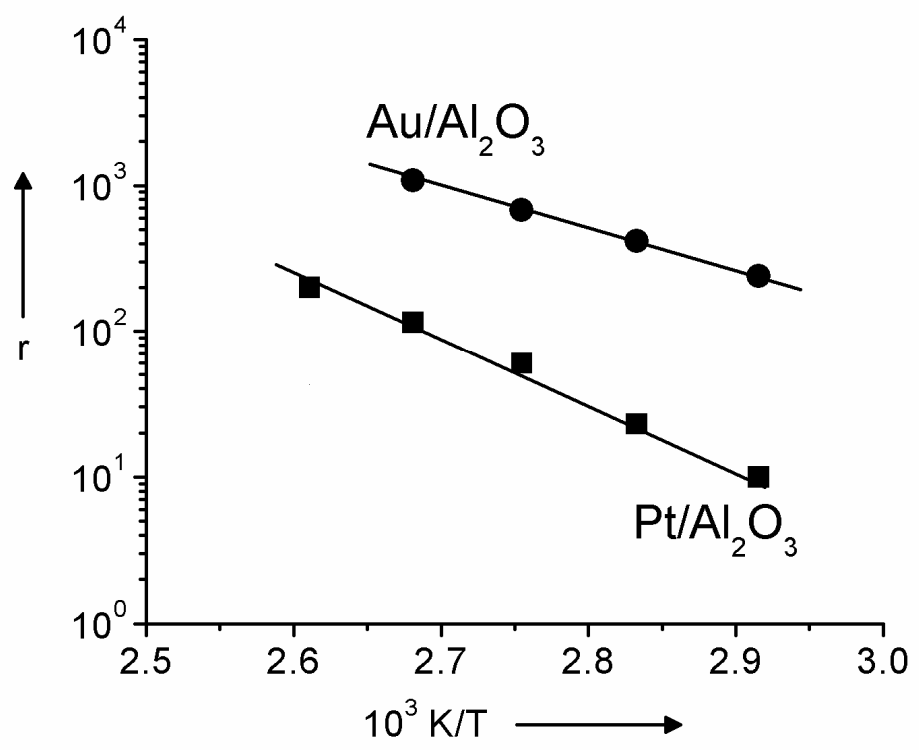


Figure 2. Turnover rates $\left(\mathrm{mol} \mathrm{s}^{-1} \mathrm{~g}\right.$-at metal $\left._{\mathrm{s}}^{-1}\right)$ calculated from TEM-visible clusters for $\mathrm{HCOOH}$

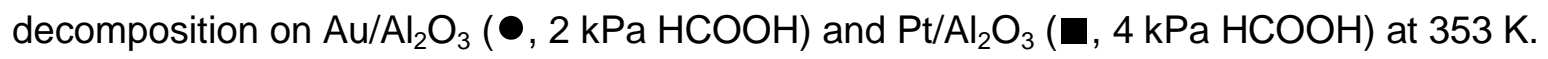

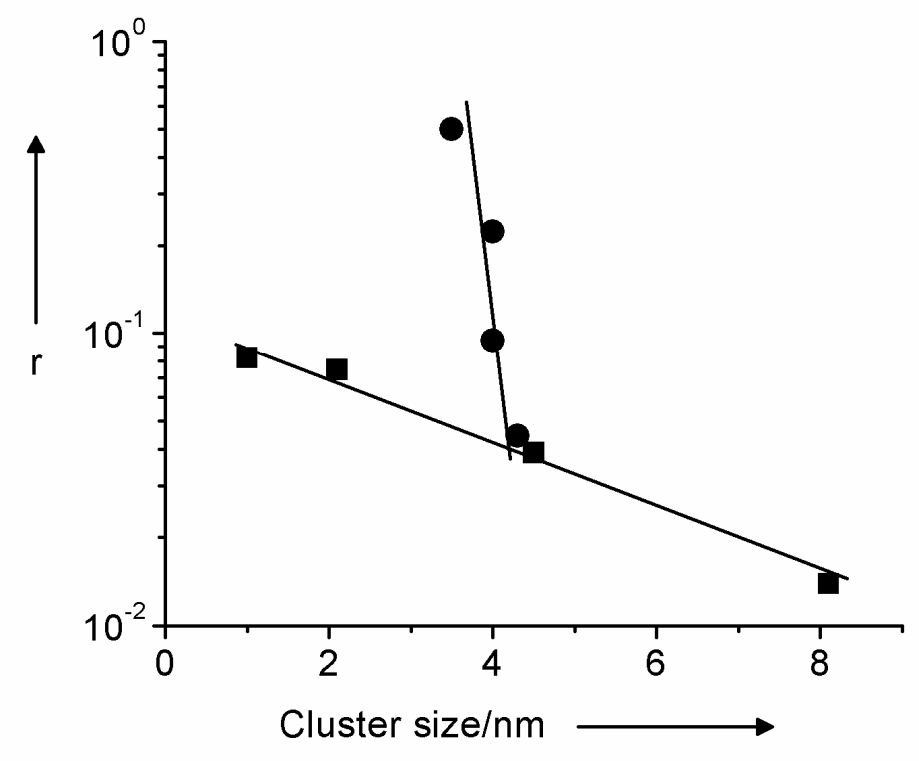


Figure 3. Influence of treatment temperature on rates $\left(\mathrm{mol} \mathrm{h}^{-1} \mathrm{~g}\right.$-at $\left.\mathrm{Au}^{-1}\right)$ for $\mathrm{CO}$ oxidation $(\bullet, 288$ $\left.\mathrm{K}, 5 \mathrm{kPa} \mathrm{CO}, 2 \mathrm{kPa} \mathrm{O}, 0.5 \mathrm{kPa} \mathrm{H}_{2} \mathrm{O}\right), \mathrm{HCOOH}$ decomposition $(\mathbf{\square}, 353 \mathrm{~K}, 2 \mathrm{kPa})$, water-gas shift $\left(\boldsymbol{\Delta}, 523 \mathrm{~K}, 5 \mathrm{kPa} \mathrm{CO}, 2 \mathrm{kPa} \mathrm{H} \mathrm{H}_{2} \mathrm{O}\right.$ ) on $\mathrm{Au} / \mathrm{Al}_{2} \mathrm{O}_{3}$ and Au cluster size from TEM ( $)$.

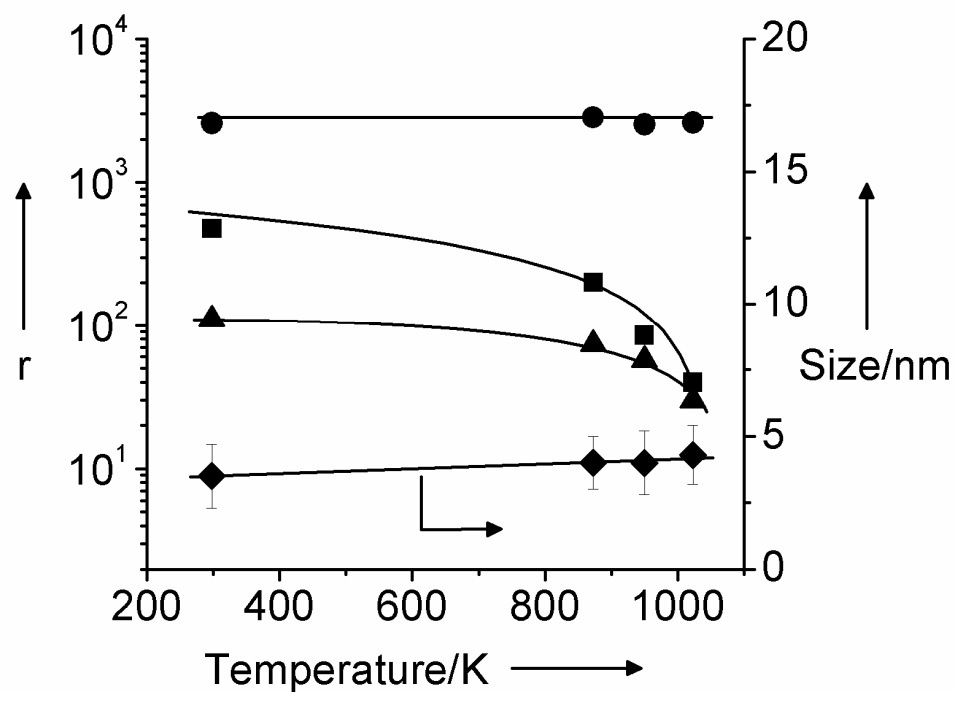


Figure 4. Effect of $\mathrm{HCOOH}$ partial pressure on the reaction rate $\left(\mathrm{mol} \mathrm{h}^{-1} \mathrm{~g}\right.$-at metal $\left.{ }^{-1}\right)$ with $\mathrm{Au} / \mathrm{Al}_{2} \mathrm{O}_{3}$ and $\mathrm{Pt} / \mathrm{Al}_{2} \mathrm{O}_{3}$ at $353 \mathrm{~K}$.

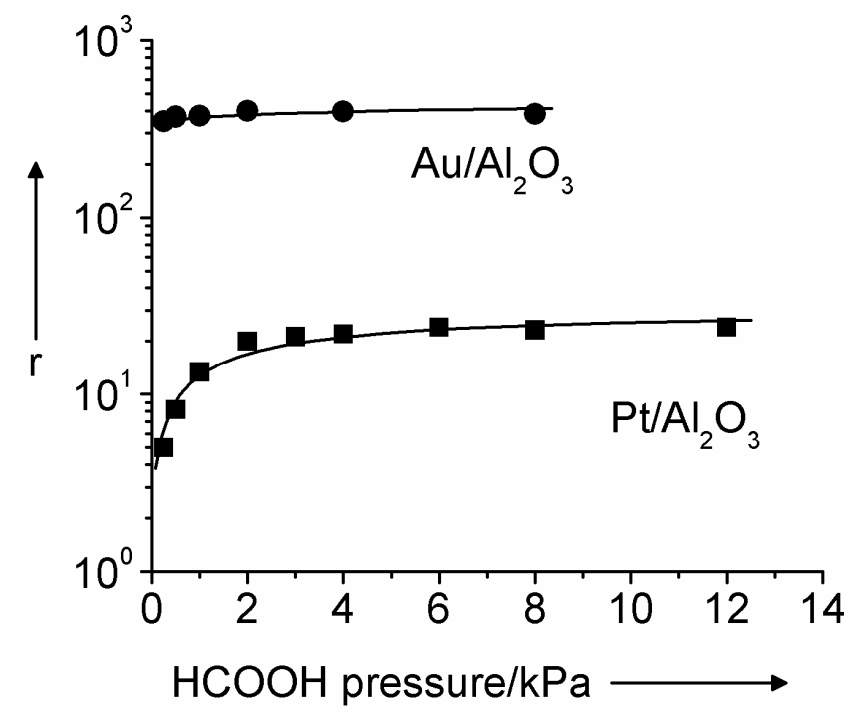




\section{Table of Contents}

$\mathrm{HCOOH}$ conversion to $\mathrm{H}_{2} / \mathrm{CO}_{2}$ : dispersed Au species grafted onto $\gamma-\mathrm{Al}_{2} \mathrm{O}_{3}$ catalyze $\mathrm{HCOOH}$ dehydrogenation more effectively than Pt clusters, previously reported as the most active metal. Dehydrogenation occurs via $\mathrm{H}$-assisted formate decomposition on $\mathrm{Au}$ species undetectable by microscopy. No $\mathrm{CO}$ is detected in $\mathrm{H}_{2} / \mathrm{CO}_{2}$ products, making them suitable for use in lowtemperature fuel cells. The kinetic relevance of $\mathrm{H}_{2}$ formation steps leads to high hydrogen chemical potentials at active sites, which may be useful in cross-hydrogenation and deoxygenation catalysis.

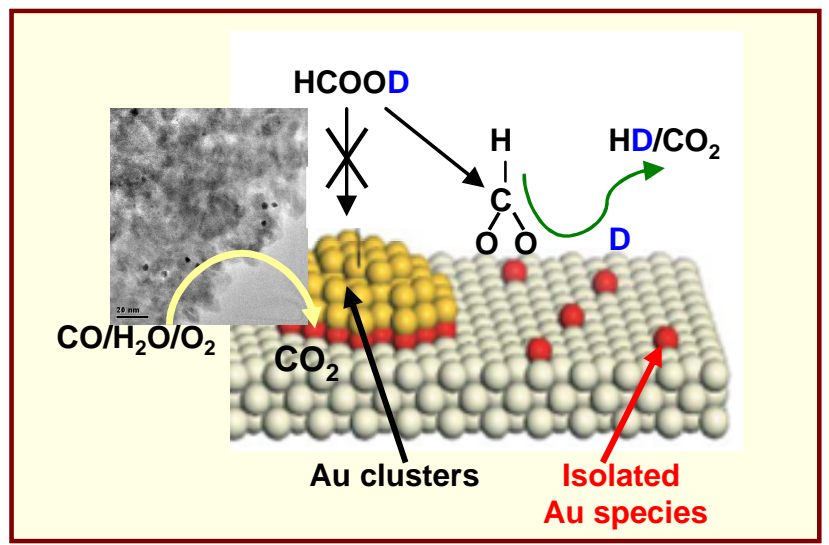

Keywords: formic acid, fuel cells, gold, heterogeneous catalysis, mechanism. 


\section{Supporting Information}

Figure 1. TEM pictures and histogram of Au cluster size distribution obtained with $\mathrm{Au} / \mathrm{Al}_{2} \mathrm{O}_{3}$ treated in $\mathrm{O}_{2} / \mathrm{He}$ at $298 \mathrm{~K}$ for $2 \mathrm{~h}$.
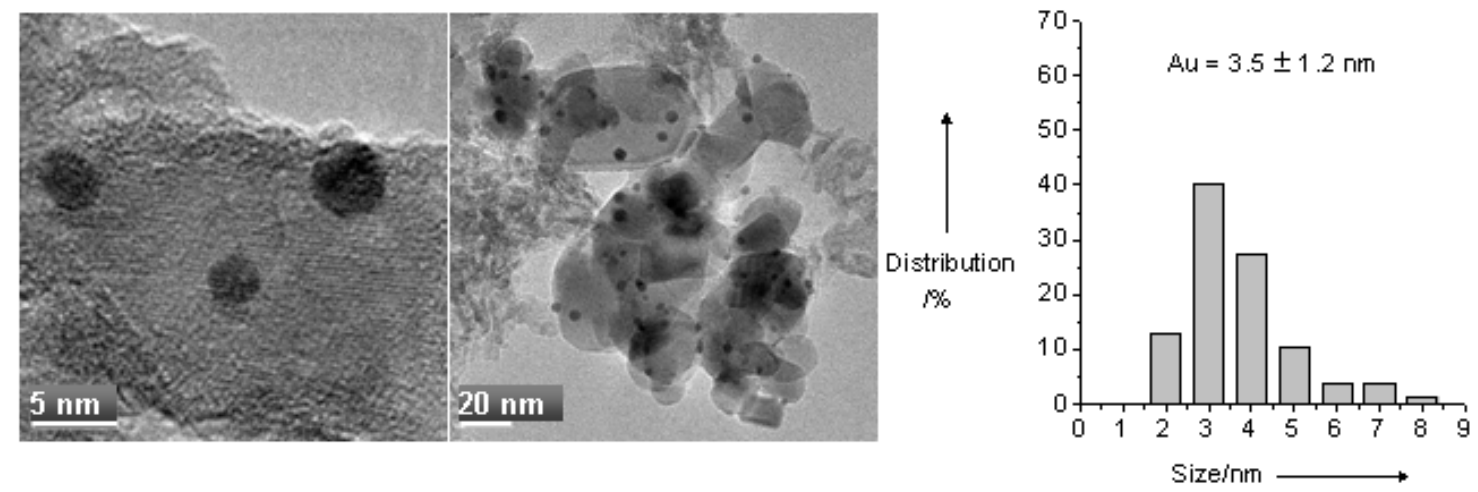
Figure 2. TEM pictures and histogram of Au cluster size distribution obtained with $\mathrm{Au} / \mathrm{Al}_{2} \mathrm{O}_{3}$ treated in $\mathrm{O}_{2} / \mathrm{He}$ at $873 \mathrm{~K}$ for $2 \mathrm{~h}$.
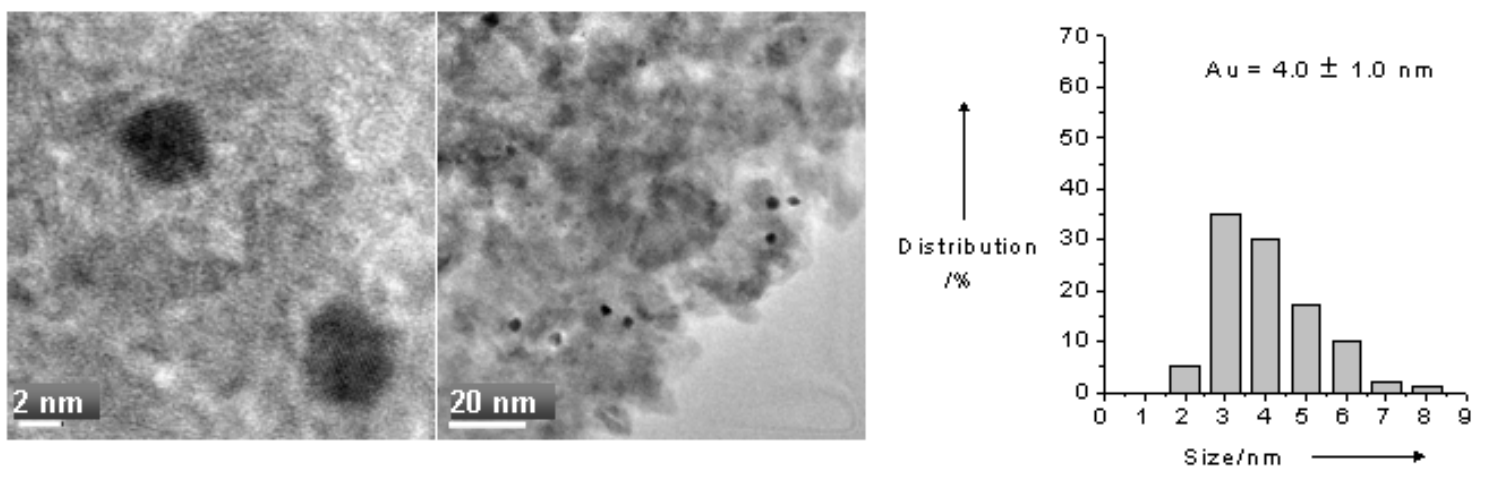
Figure 3. TEM pictures and histogram of Au cluster size distribution obtained with $\mathrm{Au} / \mathrm{Al}_{2} \mathrm{O}_{3}$ treated in $\mathrm{O}_{2} / \mathrm{He}$ at $950 \mathrm{~K}$ for $2 \mathrm{~h}$.
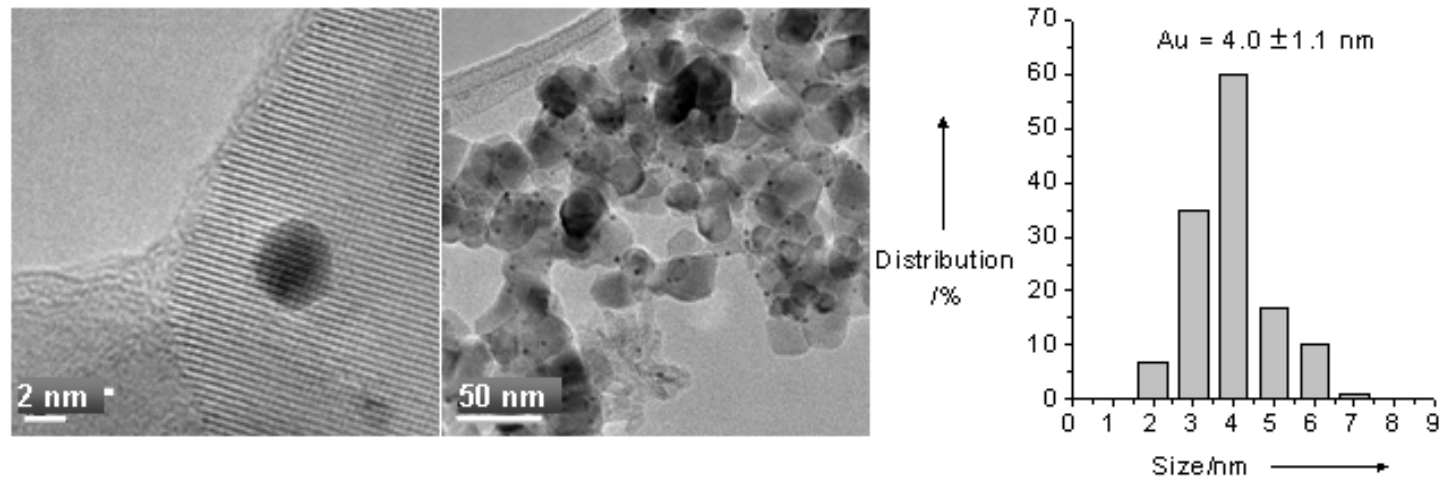
Figure 4. TEM pictures and histogram of Au cluster size distribution obtained with $\mathrm{Au} / \mathrm{Al}_{2} \mathrm{O}_{3}$ treated in $\mathrm{O}_{2} / \mathrm{He}$ at $1073 \mathrm{~K}$ for $2 \mathrm{~h}$.
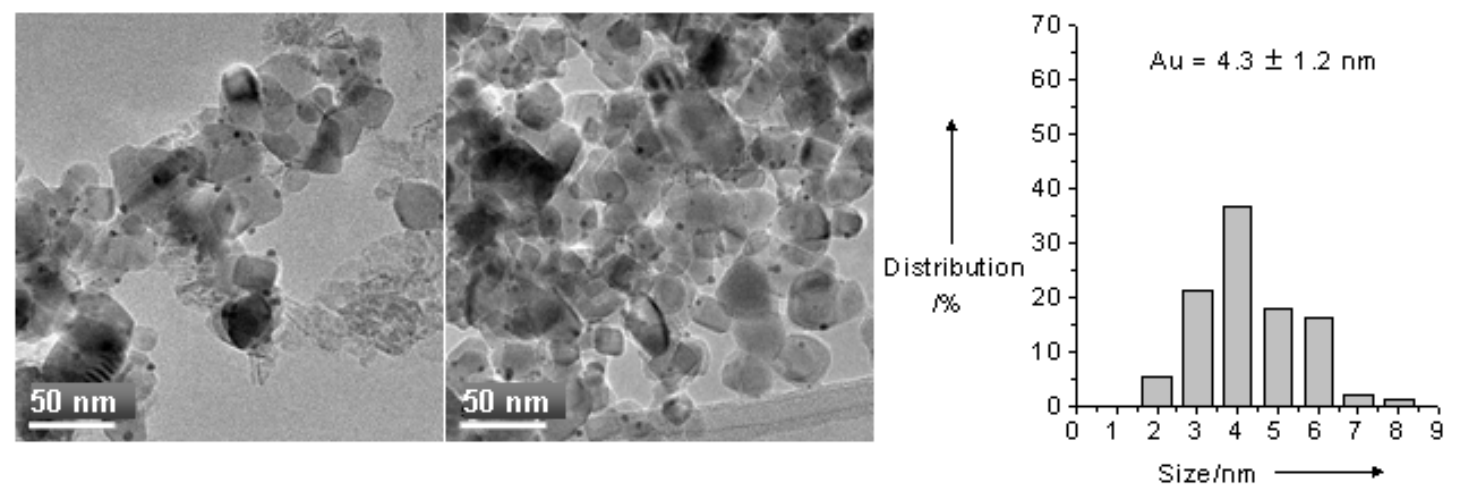